\title{
Nanoparticles as a Platform for Antimicrobial Drug Delivery
}

\author{
Satish Patel ${ }^{1}$, Deependra Singh ${ }^{1}$, Shikha Srivastava ${ }^{1}$, Manju Singh $^{1}$, Kamal Shah $^{2}$, \\ Durgesh Nandini Chauahn ${ }^{3}$, Nagendra S Chauhan,"* \\ ${ }^{1}$ University Institute of Pharmacy, Pt. Ravishankar Shukla University, India \\ ${ }^{2}$ Institute of Pharmaceutical Research, GLA University, Mathura, India \\ ${ }^{3}$ Columbia Institute of Pharmacy, Raipur (C.G.), India \\ ${ }^{4}$ Drug Testing Laboratory and Research Center (AYUSH Lab), India
}

Copyright $\bigcirc 2017$ by authors, all rights reserved. Authors agree that this article remains permanently open access under the terms of the Creative Commons Attribution License 4.0 International License

\begin{abstract}
The hasty developments in nanotechnology will have intense impact on various areas of therapeutic applications like drugs and bioactive delivery, tissue engineering, and other application. This review mainly emphasized on the nanoparticle systems for delivery of antimicrobial drug. Various antimicrobial agents have been used to kill or inhibit the growth of microbes such as bacteria, fungi and viruses. As the pharmacological actions of these drugs have been well established, feeble delivery and degradation could lead to insufficient therapeutic index and cause side effects. Nanoparticles have many advantages like small and controllable size, large surface area to mass ratio, and functionalizable structure. These properties make the nanoparticles, a suitable delivery system of antimicrobials. Along with this, it also overcomes the limitations intra-additional antimicrobial therapeutics. In last few years, development and fabrication of antimicrobial agent in nanoparticle systems has evolved as an innovative and promising alternative that increases therapeutic effectiveness and overcoming the undesirable side effects. In this chapter, we focused on the current progress and challenges in producing nanoparticle system for antimicrobial drugs delivery for the treatment of microbial diseases.
\end{abstract}

Keywords Nanoparticles, Nanotechnology, Antimicrobial Drug Delivery

\section{Introduction}

Microbial infections remain foremost causes of morbidity and mortality in hospitals around the world. The innovation of miracle drugs called antibiotics in the $20^{\text {th }}$ century leading a histrionic reduction in death and illness from these infectious diseases. Plentiful antimicrobial agents have been used to eradicate the microbes. Despite the fact the therapeutic efficiency of available drugs and treatment has been well proven, incompetent and deprived delivery of antimicrobial agents could consequence in insufficient therapeutic index and causing adverse effects like nausea, vomiting, irritation, scaling and gut microbial flora reduction. Along with developing multidrug resistant microbial strains, however, variations in the society, environment, technology and developing microorganisms are contributing to the emergence of new diseases and development of antimicrobial resistance (1). The continuing presence of antibiotic resistance in pathogenic and opportunistic microorganisms forces the pharmaceutical companies and the researcher community to continuously develop novel antibacterial drug, drug targets and delivery system to improve the activity against multidrug-resistant bacteria. In the current scenario, the progress of molecular nanostructures through precise particle size and shape is of prominent interest in biomedical applications like delivery of antimicrobial agents. Nanoscale materials/polymers have emerged up as novel antimicrobial agents and delivery system because of high surface area to volume ratio and distinctive properties $(2 ; 3)$. Due to various metallic and polymeric nanoparticles (4) have confirmed antimicrobial activities, the development of novel applications in this field makes them an attractive alternative to antibiotics.

Earlier, before discovery of chemotherapeutics, many herbs and various inorganic antimicrobials such as silver and copper etc. were used to cure microbial infections. In the recent times, the advances in the field of nanoscience and nanotechnology has provide opportunities for the nanosized inorganic and organic particles which are leading applications as improvements in industrial, medicine and therapeutics, synthetic textiles and food packaging products $(5 ; 6)$. Nano-technological applications in medicine have generated an entirely new field of technology that is set to bring momentous advances in the management of various 
diseases (7).

In earlier decades, the application of nanotechnology, particularly the use of nanoparticles for antibiotic/drug delivery, has produced noteworthy impact in management of infectious diseases. Various systems for delivery of nanoparticles like gels, liposome, polymeric nanoparticles, dendrimers, and inorganic nanoparticles, have acknowledged momentous attention. Antimicrobial molecules loaded into nano-carriers by different methods like chemical synthesis, cross-linking, physical encapsulation, adsorption, to show an improved pharmacokinetic profile and therapeutic index when related to their free form (8). Innumerable nanoparticle-based drug delivery systems have been approved for clinical use to treat a variety of infectious diseases, and a number of formulations are now under various stages of pre-clinical and clinical tests (9). Due to advancement in fabrication, green synthesis multifunctional nanoparticles, various inventive approaches have emerged, more work on improving on nanoparticle therapeutic efficacy against microbial infection. In this chapter, we discuss about nanoparticle approaches having significant potential to improve upon current treatments. Researches and investigations were made in this arena provide wonderful prospects for alternative and more effective antimicrobial approaches that amend the pharmacokinetics properties of antibiotics and produce novel antibiotics with novel inhibition mechanisms.

\section{Nanoparticles}

The focus of pharmaceutical research is being steadily shifted from the development of new chemical entities to the development of novel drug delivery system of existing drug molecule to maximize their effect in term of therapeutic and patient protection (10). Various novel drug delivery system like transdermal patches, Microspheres, Nanoparticles, Resealed erythrocytes, Ocusert, Depots, Liposomes, Niosomes, Buccal films etc., offer several advantages over the conventional drug delivery systems (11). Moreover, the development of novel drug delivery systems is going to be the outmost need of pharmaceutical industry especially after enforcement of product patent. Nanoparticles attract an increasing interest in contemporary drug research because they could be used as a very efficient drug delivery system. Nanotechnology is evolving as a rapidly growing field with its application in various fields of science and research for the purpose of producing new substances and molecules at the nanoscale level (12). The word "nano" is used to show one billionth of a meter or $10^{-9}$. The term "Nanotechnology" was first used by a Japanese scientist Professor Norio Taniguchi in 1974 to define precision manufacturing of materials at the level of nanometer. Nanotechnology deals with novel technology that provides a platform for development and exploration of biological systems, and offers various stimulus models for bio-assembled components. Nano-structured materials whichever inorganic or organic exhibited numerous features like optical and catalytic. These properties mainly depend on the size and shape of prepared nanoparticles.

Nanoparticles are defined as particulate dispersions or solid particles or groups of atoms in the size range of $1-100 \mathrm{~nm}$. "Nano" is a Greek word identical to dwarf means extremely small. The use of nanoparticles is getting impulse in the present century as they having defined chemical, optical and mechanical properties.

Nanoparticles, first developed around 1970, they were initially devised as carriers for vaccines and anticancer drugs. The drugs may be enclosed inside the sphere of the nanoparticle or linked to the surface. Once they are at the target site, the drug payload may be released from the nanoparticle by diffusion, swelling, erosion or degradation. Active systems are also possible, e.g. drug release in response to the input of external energy such as targeted ultrasound, light or magnetic field. Nanoparticles have been successfully used in nano-chemistry to enhance the immobilization and activity of catalysts, (13) in medical and pharmaceutical nano-engineering for delivery of therapeutic agents, (14) in chronic disease diagnostics, and in sensors (15). Nanoparticles have been also used in clothing and in the food industry to limit bacterial growth $(16 ; 17)$.

\subsection{Properties of Nanoparticles}

- Bulk material should have constant physical properties regardless of its size, but at the nanoscale size-dependent properties are often observed. Thus, the properties of materials change as their size approaches the nanoscale and as the percentage of atoms at the surface of a material becomes significant.

- For bulk materials larger than one micrometer (or micron), the percentage of atoms at the surface is insignificant in relation to the number of atoms in the bulk of the material. The interesting and sometimes unexpected properties of nanoparticles are therefore largely due to the large surface area of the material, which dominates the contributions made by the small bulk of the material.

- Nanoparticles of usually yellow gold and gray silicon are red in color; gold nanoparticles melt at much lower temperatures (nearly $300^{\circ} \mathrm{C}$ for $2.5 \mathrm{~nm}$ size) than the gold slabs $\left(1064^{\circ} \mathrm{C}\right)$.

- Suspensions of nanoparticles are possible since the interaction of the particle surface with the solvent is strong enough to overcome density differences, which otherwise usually result in a material either sinking or coating in a liquid.

- Nanoparticles also often possess unexpected optical properties as they are small enough to connect the electrons and produce quantum effects. For example 
gold nanoparticles appear deep red to black in solution.

- The high surface area to volume ratio of nanoparticles provides a tremendous driving for drug diffusion.

- Moreover, nanoparticles have been found to impart some extra properties to various day to day products. For example the presence of titanium dioxide nanoparticles imparts what we call the self-cleaning effect, and the size being nano-range, the particles cannot be observed. Zinc oxide particles have been found to have superior UV blocking properties compared to its bulk substitute. This is one of the reasons why it is often used in the preparation of sunscreen lotions, and is completely photostable.

\subsection{Advantages of Nanoparticles}

Nanoparticles can offer significant advantages over the traditional delivery mechanisms in terms of various aspects (18). Nanoparticles have capability of both passive and active drug targeting due to its particle size and surface characteristics. With the use of nanoparticles, there is increase in drug therapeutic efficacy and reduction in side effects due to altering organ distribution of the drug and subsequent clearance of the drug. Nanoparticles also control and sustain the release of the drug. On the basis of choice of matrix constituents, nanoparticles release and degradation properties can be easily modulated. Nanoparticles also have an advantage of Site-specific targeting. It can be achieved by using targeting ligands to surface of particles. Nanoparticles used for various routes of administration including oral, nasal, parenteral, intraocular etc. Along with these nanoparticles have high stability, capability to transport both hydrophilic and hydrophobic molecules, high ratio of surface area to mass, high reactivity, prolonged systemic circulation, precise drug targeting and concurrent delivery of multiple drugs (18).

\subsection{Limitations of Nanoparticles}

In spite of these advantages, nanoparticles do have limitations.

- $\quad$ For example, their small size and large surface area can lead to particle-particle aggregation, making physical handling of nanoparticles difficult in liquid and dry forms.

- In addition, small particles size and large surface area readily result in limited drug loading and burst release.

Table 1 state about the different parameters for characterization nanoparticles and instruments used for these characterizations.

Table 1. Different Parameters for characterization of Nanoparticles

\begin{tabular}{|c|c|}
\hline Parameters & Instrument used \\
\hline Particle size \& size distribution & Zetasizer, Photon correlation spectroscopy, Mercury porosimetry, Laser diffractometry \\
\hline Particle Morphology & $\begin{array}{c}\text { Laser droplet anemometry, Zeta potentiometer } \\
\text { microscopy (AFM) }\end{array}$ \\
\hline Charge determination & $\begin{array}{c}\text { Water contact angle measurements, rose bangle (dye) binding, hydrophobic interaction } \\
\text { chromatography, X-ray photoelectron spectroscopy }\end{array}$ \\
\hline Surface hydrophobicity & Static secondary ion mass spectrometry \\
\hline Chemical analysis of surface & Differential scanning calorimetry \\
\hline Carrier drug interaction & Critical flocculation temperature \\
\hline Nanoparticle dispersion stability & In-vitro release characteristic under physiologic \& sink condition \\
\hline Release profile & Bioassay of drug extracted from nanoparticle, chemical analysis of drug \\
\hline Drug stability & \\
\hline
\end{tabular}




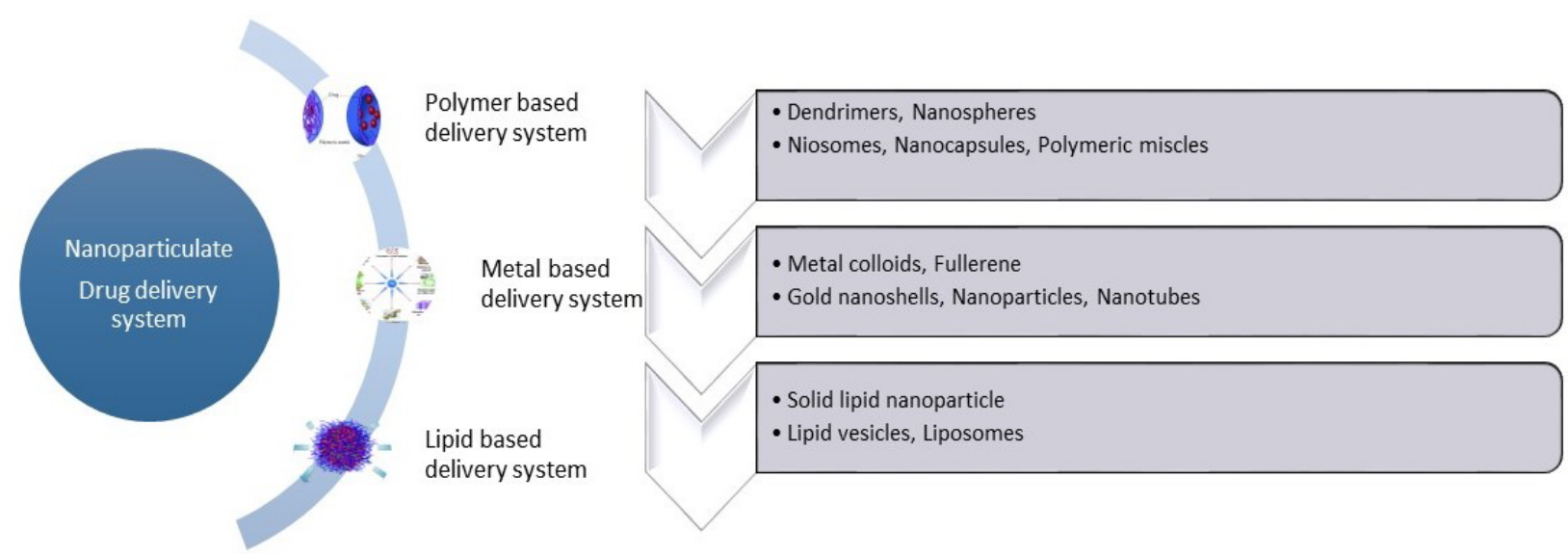

Figure 1. Types of nano-particulate delivery systems

\section{Nanoparticles as Platform for Antimicrobials Delivery}

These characteristic physicochemical properties have advantages in delivering and targeting to the target site, consequently minimizing adverse effect. Additionally, these could move in cells through endocytosis and consequently release the antibacterial agent to eliminate infections. In fact, a number of researches on nanoparticles based antibiotics have been developed and reviewed.

\subsection{Metallic Nanoparticles}

The continuous growing resistance of microbes to antibiotics causes severe health complications in current years. To confrontation with these problems, modern researcher identified the novel application by combining nanotechnology with intrinsic antimicrobial activity of the metals. Metallic nanoparticles are being utilized in many field of science with engineering comprising medical fields also and are still attract the scientists to invent new dimensions for their respective worth which is generally credited to their corresponding small sizes. In present scenario, the research in nanoparticle field is mainly focused on its synthesis or green synthesis not much on its applications. Research mainly focused on green synthesis because of disadvantages of physical and chemical methods like considerable environmental defect, laborious and expensive (19). The metallic nanoparticles are most promising because of good antibacterial properties due to their large surface area to volume ratio, which is coming up as the current interest in the researchers due to the growing microbial resistance (20). Various Metals like copper, zinc, titanium, magnesium, gold (21) and metal oxides have been widely studied for their antimicrobial activities. Metal oxide nanoparticles, recognized due to its highly potent antibacterial effect, include iron oxide $\left(\mathrm{Fe}_{2} \mathrm{O}_{3}\right)$, titanium oxide $\left(\mathrm{TiO}_{2}\right)$, copper oxide $(\mathrm{CuO})$, and zinc oxide $(\mathrm{ZnO})$. These nanoparticles mainly synthesis by either reducing the particle size by mechanical/ ball milling, chemical etching, microwave decomposition, thermal/ laser ablation and particle sputtering by chemical precipitation, microwave hydrothermal method, electrochemical precipitation, hydrothermal synthesis, vapor deposition, solvo-thermal method, atomic and molecular condensation, sol gel process, spray pyrolysis, laser pyrolysis, aerosol pyrolysis or by green synthesis using bacteria, plant extract and fungus (22). In the Table 2, 3 and 4, we briefly discussed about various metallic nanoparticle, their mechanism of action, application and limitation and toxicity. 
Table 2. List of metallic nanoparticles

\begin{tabular}{|c|c|c|c|c|c|}
\hline S.N. & Nanoparticles & Method of Preparation & Bacteria \& Disease treated & Advantage & Reference \\
\hline 1. & $\begin{array}{l}\text { Metal nanoparticles } \\
(\mathrm{Ag}, \mathrm{Pt})\end{array}$ & Ultrasonic irradiation method & Streptococcus aureus and Escherichia coli & Show antimicrobial activity of metals & 23 \\
\hline 2. & Silver (Ag) nanoparticle & Chemical Synthesis & $\begin{array}{l}\text { Gram negative bacterial strains, Escherichia coli and } \\
\text { Pseudomonas aeruginosa }\end{array}$ & $\begin{array}{c}\text { Show antimicrobial activity of such hybrids } \\
\text { materials }\end{array}$ & 10,24 \\
\hline 3. & Copper nanoparticles & Modified polyol method & $\begin{array}{c}\text { Micrococcus luteus, Streptococcus aureus, Eescheria coli, } \\
\text { Klebsiella pneumoniae, and Pseudomonas } \\
\text { aeruginosa }\end{array}$ & Show antimicrobial activity of metals & 25 \\
\hline 4. & $\begin{array}{l}\text { Cobalt oxide } \\
\text { nanoparticles }\end{array}$ & $\begin{array}{l}\text { Simple urea-based } \\
\text { Thermal decomposition } \\
\text { method }\end{array}$ & $\begin{array}{c}\text { Gram-positive } \\
\text { And Gram-negative bacteria }\end{array}$ & Show antimicrobial activity of metals & 26 \\
\hline 5. & $\begin{array}{l}\text { Quercetin-Acetylcholine- } \\
\text { Selenium Nanoparticles }\end{array}$ & -------- & Multidrug-resistant super bugs & $\begin{array}{l}\text { Synergistic properties of both drug enhance the } \\
\text { antibacterial activity of Selenium Nanoparticles }\end{array}$ & 27 \\
\hline 6. & $\begin{array}{c}\mathrm{CaO} \\
\text { Nanoparticles } \\
\end{array}$ & Microwave irradiated synthesis & $\begin{array}{c}\text { Gram negative and gram positive bacteria and pathogenic } \\
\text { yeast }\end{array}$ & $\begin{array}{l}\text { Cheap, Nontoxic and inhibits the biofilm } \\
\text { formation }\end{array}$ & 28 \\
\hline 7. & $\begin{array}{l}\text { Dextran-and polyacrylic } \\
\text { acid-coated ceria } \\
\text { nanoparticles }\end{array}$ & -------- & Pseudomonas aeruginosa & $\begin{array}{c}\text { Enhanced biocompatibility properties, } \\
\text { Minimized toxicity, and reduced clearance by the } \\
\text { immune system }\end{array}$ & 29 \\
\hline 8. & $\begin{array}{l}\text { Carboxyl-capped bismuth } \\
\text { Nanoparticles }\end{array}$ & ------- & Helicobacter pylori & ------- & 30 \\
\hline 9. & $\mathrm{ZnO}$ nanoparticles & Precipitation method & Gram negative and gram positive bacteria & $\begin{array}{l}\text { More stable and potent antibacterials against } \\
\text { broad spectrum of microorganisms }\end{array}$ & 31 \\
\hline 10. & $\begin{array}{c}\text { Selenium doped } \mathrm{ZnO} \\
\text { nanoparticles }\end{array}$ & Mechano-chemical method & ------- & - & ------- \\
\hline 11. & $\begin{array}{l}\text { Ampicillin loaded gold } \\
\text { nanoparticles }\end{array}$ & Chemical Synthesis & Gram-negative and Gram-positive bacteria & $\begin{array}{l}\text { Formed a potent system with new properties } \\
\text { To destroy ampicillin-resistant bacteria }\end{array}$ & 32 \\
\hline 12. & $\begin{array}{c}\text { Cefaclor loaded gold } \\
\text { nanoparticle }\end{array}$ & One pot synthesis & Escherichia coli and Streptococcus aureus & ------- & 33 \\
\hline 13. & $\begin{array}{l}\text { Polyvinylpyrrolidone } \\
\text { coated silver } \\
\text { Nanoparticles }\end{array}$ & ------- & HIV-I & $\begin{array}{c}\text { Effective } \\
\text { cyto-protective and post-infected } \\
\text { anti-HIV-1 activities toward } \\
\text { Hut/CCR5cells. }\end{array}$ & 34 \\
\hline 14. & $\begin{array}{l}\text { Metallic nanoparticle } \\
(\mathrm{Ag}, \mathrm{Cu}, \mathrm{W})\end{array}$ & Pressurised gyration & Pseudomonas aeruginosa & $\begin{array}{c}\text { Enhanced antimicrobial efficiency than pure } \\
\text { poly(methyl methacrylate)fibres }\end{array}$ & 35 \\
\hline 15. & $\begin{array}{c}\text { Silver } \\
\text { Nanoparticles with } \\
\text { titanium oxides }\end{array}$ & ------- & $\begin{array}{l}\text { A.niger, P.spinulosum and S.chartarum, and E.coli and S. } \\
\text { epidermidis }\end{array}$ & $\begin{array}{c}\text { Antimicrobial efficacy enhanced by titanium } \\
\text { oxides }\end{array}$ & 36 \\
\hline 16. & $\begin{array}{l}\text { Titanium dioxide } \\
\text { nanoparticles }\end{array}$ & $\begin{array}{l}\text { Green synthesis and advanced } \\
\text { hydrothermal method }\end{array}$ & $\begin{array}{c}\text { Staphylococcus aureus, Escherichia coli, Bacillus subtilis, } \\
\text { Pseudomonas aeruginosa, Candida albicans, and Aspergillus } \\
\text { niger }\end{array}$ & $\begin{array}{l}\text { Enhanced antibacterial activity against } \\
\text { Gram-positive bacteria }\end{array}$ & 37 \\
\hline
\end{tabular}


Table 3. List of Metal/Metal oxide nanoparticle with their mechanism of action

\begin{tabular}{|c|c|c|c|}
\hline S. No. & $\begin{array}{l}\text { Metal/ Metal oxide } \\
\text { nanoparticle }\end{array}$ & Mechanism of action & Reference \\
\hline 1. & Silver & $\begin{array}{l}\text { Create holes in the cell wall of microbes by increasing the cell membrane permeability and in capacitating the respiratory chain. } \\
\text { Inhibit and interrupt protein structure by binding to thiol and amino groups. } \\
\text { Photo-catalytic and induce reactive oxygen species. } \\
\text { Poisoning respiratory enzymes and components of the microbial electron transport system } \\
\text { Binds to surface, altering the membrane function, and } \\
\text { Bind to DNA bases and inhibiting replication }\end{array}$ & $\begin{array}{l}38 \\
39 \\
40 \\
41 \\
42\end{array}$ \\
\hline 2. & Titanium dioxide & $\begin{array}{l}\text { Photo-catalytic } \\
\text { Stimulates reactive oxygen species burst. } \\
\text { Reactive oxygen species destruct the cell membrane, DNA, and macromolecules and various functions of the bacterial cell }\end{array}$ & $\begin{array}{l}43, \\
44\end{array}$ \\
\hline 3. & Gold & $\begin{array}{l}\text { Destroy bacteria via photo-thermal heating } \\
\text { Generate holes in the cell wall resulting in the leakage of cell contents and cell death } \\
\text { Bind to the DNA of bacteria and inhibit the uncoiling and transcription of DNA }\end{array}$ & $\begin{array}{l}33, \\
45\end{array}$ \\
\hline 4. & Iron oxide & $\begin{array}{l}\text { Depolymerize the polysaccharides, } \\
\text { Break DNA strands, can initiate lipid per oxidation or inactivate the enzymes }\end{array}$ & 46 \\
\hline 5. & Magnesium oxides & $\begin{array}{c}\text { Inducing reactive oxygen species } \\
\text { Inhibit essential enzymes of the bacteria }\end{array}$ & 44 \\
\hline 6. & Zinc Oxide & $\begin{array}{c}\text { Cell wall damage due to ZnO-localized interaction } \\
\text { Enhanced membrane permeability } \\
\begin{array}{c}\text { Internalization of nanoparticles due to loss of proton motive force and uptake of toxic dissolved zinc ions led to mitochondria weakness, } \\
\text { intracellular outflow, and releasing expression of oxidative stress caused eventual cell growth inhibition and cell death } \\
\text { Reactive oxygen generation }\end{array}\end{array}$ & $\begin{array}{l}47 \\
48, \\
49\end{array}$ \\
\hline 7. & Nitric Oxide & Affecting reactive nitrogen species than reactive oxygen species & 50 \\
\hline 8. & Copper oxide & $\begin{array}{l}\text { Membrane disruption and Reactive oxygen species production } \\
\text { Interact with DNA molecules and intercalate with nucleic acid strands. } \\
\text { Disrupt biochemical processes. }\end{array}$ & 43 \\
\hline 9. & Aluminum oxide & $\begin{array}{l}\text { Increases diffusion and accretion inside the microbial cells } \\
\text { Create spit formation, increases perforation, and causes membrane disorganization and also causes microbial cell death }\end{array}$ & 51 \\
\hline
\end{tabular}


Table 4. Limitation and toxicity of Metallic nanoparticle

\begin{tabular}{|c|c|c|c|}
\hline S. No. & Metallic nanoparticle & Limitation/Toxicity & Reference \\
\hline 1. & Silver & $\begin{array}{c}\text { Aggregation of particles into large particles due to high surface energy leads to loss of } \\
\text { antibacterial activity. Oral toxicity, eye irritation, corrosion, and dermal toxicity }\end{array}$ & 52 \\
\hline 2 & Silicon oxide & $10 \mathrm{~nm}$ particle having strong impact on cell viability and genotoxic effects & 52 \\
\hline 3. & Gold nanoparticles $(4-5 \mathrm{~nm})$ & Inflammation, accretion of gold in lungs, and an increased number of macrophages & 53 \\
\hline
\end{tabular}

\subsection{Polymeric Nanoparticles}

Polymeric nanoparticles with biodegradable and biocompatible polymers are good candidates as particulate carrier for antimicrobial agent and drug delivery and there has been considerable interest in the use of nanoparticles as potential delivery systems. Numerous investigations have shown that nanoparticles can not only improve the stability of therapeutic agents against enzymatic degradation, but by modulating polymer characteristics, they can also achieve desired therapeutic levels in target tissues for the required duration for optimal therapeutic efficacy $(54,1)$. Depending on their composition and intended use, they can be administered orally, parenterally, or locally (54). Different nanoparticles manufacturing methods were described allowing modification of physicochemical characteristics such as size, structure, morphology, surface texture and composition to meet different requirements.

Nanoparticles act on microbes by releasing antibiotics, antimicrobial peptides, and antimicrobial agents or by contact-killing like quaternary ammonium compounds etc. Cationic groups (with long hydrophobic chains) are capable to lysis the membrane to penetrate and burst the bacterial membrane and lead to death $(52,55)$.

Lots of the nanoparticle therapeutics in research are polymeric nanoparticles, which have been comprehensively explored as platform for drug delivery. Polymeric nanoparticles are fabricated from biocompatible and biodegradable polymers. Polymeric nanoparticles are formulated by a self-assembly process using block-copolymers comprising of two or more polymer chains with different hydrophilicity. Polymeric nanoparticles have been framed to encapsulate either hydrophilic or hydrophobic drug molecules, as well as macromolecules such as proteins, peptides and nucleic acids (56).

The main issues in this field are the loading efficiency, stability of bioactive agent during preparation and release, release profiles and surface modification. Particles size and surface property (surface charge and hydrophobic or hydrophilic property) are primary factors for the in-vivo fate of nanoparticles. Surface modification of nanoparticles has been achieved mainly by two methods:

- Surface coating with hydrophilic polymers/surfactants

- Development of biodegradable copolymers with charged functional group or hydrophilic segments.

\subsubsection{Methods of Preparation of Polymeric Nanoparticles}

Method of preparation are mainly depends upon the physico-chemical characteristic of polymers and the drugs. They are classified as-

- Amphiphilic macromolecular cross linking

I Heat cross-linking

II Chemical cross-linking

- Polymerization methods

I Emulsion polymerization

II Dispersion polymerization

III Interfacial complexation

IV Interfacial condensation polymerization

- Polymer precipitation methods

I Solvent extraction/ evaporation methods.

II Solvent displacement methods

III Salting out.

Table 5. Polymer used in nanoparticle preparation with advantages

\begin{tabular}{|c|c|}
\hline Polymer & Advantage \\
\hline Poly(alkyl cyano acrylate) & Improve in-vitro in-vivo and drug stability. \\
\hline Poly(alkyl cyano acrylate)polyester & Targeting RES for intracellular targeting. \\
\hline Polyester with adsorbed PEG & Prolong systemic drug effect, avoid uptake by RES. \\
\hline Poly (methyl meth acrylate) & Enhanced immune response. \\
\hline Poly (methyl meth acrylate) & Enhanced bioavailability protection from GIT \\
\hline Poly(alkylcyano acrylate) & Improve retention of drug /reduced washout. \\
\hline Gelatin & Enhanced delivery and significant higher expression level. \\
\hline Chitosan & Enhanced delivery and significant higher expression level. \\
\hline PLGA & Enhanced delivery and significant higher expression level. \\
\hline Poly-alkyl cyano acrylate & Improve absorption /permeation. \\
\hline
\end{tabular}


Table 6. List of polymeric nanoparticles

\begin{tabular}{|c|c|c|c|c|c|}
\hline S. No. & Nanoparticles System & Method of Preparation & Bacteria \& Disease treated & Advantage & Reference \\
\hline 1. & $\begin{array}{l}\text { Quaternary ammonium polyethylen imine } \\
\text { Nanoparticles }\end{array}$ & Chemical Synthesis & $\begin{array}{c}\text { S.aureus, } \\
\text { S.epidermidis,Enterococcus faecalis, } \\
\text { P.aeruginosa } \text { and E.coli } \\
\end{array}$ & $\begin{array}{l}\text { Long lasting antimicrobial effect against a wide } \\
\text { range of bacteria and effect on biocompatibility }\end{array}$ & $\begin{array}{l}57 \\
58\end{array}$ \\
\hline 2. & $\begin{array}{c}\text { Ciprofloxacin- loaded poly-isobutyl cyanoacrylate } \\
\text { nanoparticles }\end{array}$ & Emulsion polymerization & Mycobacterium avium & $\begin{array}{c}\text { Modifications } \\
\text { In the pharmacokinetic properties and augment the } \\
\text { activity }\end{array}$ & 59 \\
\hline 3. & Ampicillin-loaded polyethyl cyanoacrylate nanoparticles & Emulsion polymerization & $\begin{array}{c}\text { E.coli, } \\
\text { S.aureus, S.faecalis and S.epidermis }\end{array}$ & $\begin{array}{c}\text { Increases drug encapsulation capacity and a size } \\
\text { distribution and exhibit an activity equal or } \\
\text { More than the free drug. }\end{array}$ & 60 \\
\hline 4. & $\begin{array}{l}\text { Silver-carbene complex-loaded } \\
\text { L-tyrosine polyphosphate nanoparticles }\end{array}$ & $\begin{array}{l}\text { Water-in-oil-in-water } \\
\text { emulsion method }\end{array}$ & Cystic fibrosis and P.aeruginosa & $\begin{array}{c}\text { Sustain the release of the } \\
\text { drug }\end{array}$ & 61 \\
\hline 5. & Rifampin and azithromycin loaded PLGA nanoparticles & Emulsion techniques & Persistent chlamydial infection & Better invitro efficacy & 62 \\
\hline 6. & Nisin-loaded solid lipid nanoparticles & $\begin{array}{l}\text { Hot high pressure } \\
\text { homogenization }\end{array}$ & $\begin{array}{c}\text { Listeria monocytogenesDMST2871a } \\
\text { nd } \\
\text { Lacto bacillus plantarum TISTR850 }\end{array}$ & Sustain the antibacterial action of nisin & 63 \\
\hline 7. & $\begin{array}{c}\text { Rifampicin- loaded } \\
\text { polylactide-co- glycolide nanoparticles }\end{array}$ & $\begin{array}{c}\text { Emulsification/ solvent } \\
\text { diffusion method }\end{array}$ & $\begin{array}{c}\text { Gram-positive bacteria and } \\
\text { Tuberculosis } \\
\end{array}$ & ------- & 64 \\
\hline 8. & $\begin{array}{c}\text { Kojic acid-chitosan-tri-polyphosphate } \\
\text { nanoparticles }\end{array}$ & - & S.aureus and P.aeruginosa & -------- & 65 \\
\hline 9. & Florfenicol- loaded solid lipid nanoparticle & $\begin{array}{c}\text { Hot homogenisation and } \\
\text { ultrasonic technique }\end{array}$ & $\begin{array}{c}\text { S.aureus } \\
\text { and E.coli } \\
\end{array}$ & ------- & 66 \\
\hline 10. & Quaternary ammonium polyethylene imine nanoparticles & ------- & $\begin{array}{l}\text { S.viridans, Stenotrophomonas } \\
\text { maltophilia, E.coli } \text { and Peritonitis }\end{array}$ & ------- & 67 \\
\hline 11. & $\begin{array}{l}\text { Caffeic acid phenethyl ester } \\
\text { PLGA nanoparticle }\end{array}$ & ------- & $\begin{array}{c}\text { P.aeroginosa, E.coli, S.aureus and } \\
\text { methicillin- resistant } \\
\text { S.aureus } \\
\end{array}$ & -------- & 68 \\
\hline 12. & $\begin{array}{l}\text { Thioridazinein poly(lactic-co-glycolic) acid } \\
\text { nanoparticles }\end{array}$ & ------- & M.tuberculosis & $\begin{array}{c}\text { Reduced dosing localized targeting and sustained } \\
\text { release and reduce systemic toxicity and improve } \\
\text { the antibacterial in-vivo acticity }\end{array}$ & 69 \\
\hline 13. & Chitosan nanoparticles with chlorhexidin & ------- & Periodontitis & Enhance the antibacterial activity & 70 \\
\hline 14. & $\begin{array}{c}\text { Retinoic acid and lauric acid loaded solid lipid } \\
\text { nanoparticles }\end{array}$ & ------- & $\begin{array}{c}\text { Propionibacterium acnes, S.aureus } \\
\text { and S.epidermidis }\end{array}$ & $\begin{array}{c}\text { Innovative acne therapy and decrease the side } \\
\text { effect }\end{array}$ & 71 \\
\hline 15. & $\begin{array}{l}\text { Poly(l-glutamicacid)-capped silver nanoparticles with } \\
\text { ascorbic acid poly(lactide-co-glycolide) nanospheres }\end{array}$ & -------- & $\begin{array}{l}\text { Methicillin-resistant } \\
\text { S.aureus and E.coli }\end{array}$ & $\begin{array}{c}\text { New treatment of infections and } \\
\text { Use in wound dressings and prophylactic } \\
\text { applications } \\
\end{array}$ & 72 \\
\hline 16. & Clarithromycin loaded PLGA nanoparticle & Nano-precipitationmethod & & $\begin{array}{l}\text { Enhanced physico- } \\
\text { Chemical properties and therapeutic efficacy }\end{array}$ & 73 \\
\hline 17. & Daptomycin-loaded chitosan nanoparticles & ------- & Endophthalmitis & $\begin{array}{l}\text { Increasing the effectiveness of } \\
\text { Treatment and reducing toxicity associated with } \\
\text { systemic administration }\end{array}$ & 74 \\
\hline
\end{tabular}




\begin{tabular}{|c|c|c|c|c|c|}
\hline 18. & Clindamycin loaded PLGA hydroxyapatite nanoparticle & $\begin{array}{c}\text { Sono chemical homogeneous } \\
\text { precipitation } \\
\text { and ultrasonic } \\
\text { de-agglomeration }\end{array}$ & Wound healing & Enhance drug absorption and delivery & 75 \\
\hline 19. & $\begin{array}{c}\text { Ciprofloxacin loaded Glycosylated polyacrylate } \\
\text { nanoparticles }\end{array}$ & & $\begin{array}{l}\text { S. aureus, } \\
\text { Bacillus anthracis }\end{array}$ & $\begin{array}{l}\text { Enhanced bioavailability, } \\
\text { Increased therapeutic } \\
\text { Efficacy }\end{array}$ & 76 \\
\hline 20. & Azithromycin loaded PLGA nanoparticle & Nano-precipitationmethod & & $\begin{array}{c}\text { Better physico- } \\
\text { Chemical properties and therapeutic efficacy }\end{array}$ & 77 \\
\hline 21. & $\begin{array}{c}\text { Rifampicin, } \\
\text { isoniazid, } \\
\text { pyrazinamide loaded Alginate nanoparticles }\end{array}$ & & $\begin{array}{c}M . \\
\text { tuberculosis }\end{array}$ & $\begin{array}{c}\text { Increase drug load, } \\
\text { Pharmacokinetic activity and } \\
\text { Therapeutic efficacy }\end{array}$ & 78 \\
\hline 22. & Rifampicin loaded PLGA nanoparticle & $\begin{array}{c}\text { Emulsification/ solvent } \\
\text { diffusion method }\end{array}$ & $\begin{array}{l}\text { Gram-positive and Gram-negative } \\
\text { bacteria }\end{array}$ & $\begin{array}{c}\text { Enabling drug penetration to parasites present in } \\
\text { macrophages }\end{array}$ & 64 \\
\hline 23. & Halofantrine loaded PLA nanoparticle & & Malaria & $\begin{array}{l}\text { Improved stability, lower toxicity than free form in } \\
\text { solution and rapid uptake by tissues }\end{array}$ & 79 \\
\hline 24. & $\begin{array}{l}\text { Saquinavir loaded Polyethylene oxide } \\
\text { Modified poly(epsilon carprolactone) } \\
\text { Nanoparticles }\end{array}$ & & HIV & $\begin{array}{l}\text { Shield Saquinavir from enzyme cytochrome C } \\
\text { Metabolism and avoid P-efflux pump }\end{array}$ & 80 \\
\hline 25. & $\begin{array}{l}\text { PLGA nanoparticle entrapped eugenol and } \\
\text { trans-cinnamaldehyde }\end{array}$ & $\begin{array}{l}\text { Emulsion evaporation } \\
\text { method }\end{array}$ & Salmonell a and Listeria & Mask the hydrophobic property & 81 \\
\hline 26. & Levofloxacin loaded PLGA nanoparticle & $\begin{array}{l}\text { Emulsification-solvent-evapo } \\
\text { ration method }\end{array}$ & Pulmonary infection & Biphasic extended drug release & 82 \\
\hline
\end{tabular}


Table 7. List of Polymers for nanoparticle fabrication

\begin{tabular}{|c|c|c|c|c|}
\hline S. No. & Polymer & Composition & Action through & Reference \\
\hline 1. & Poly- $\varepsilon$-lysine & cationic homopeptide of L-lysine & Disrupting the cell membrane of bacteria & 83 \\
\hline 2. & $\begin{array}{c}\text { Quaternary } \\
\text { ammonium } \\
\text { compounds. }\end{array}$ & $\begin{array}{c}\text { Benzalkonium chloride, stearalkonium } \\
\text { chloride, and cetrimonium chloride }\end{array}$ & $\begin{array}{c}\text { Interact with surface of bacteria and denature structural } \\
\text { proteins and enzymes }\end{array}$ & 52 \\
\hline 3. & Chitosan & N-acetylglucosamine polymer chitin & $\begin{array}{c}\text { Interrupted membrane functions like destabilization of } \\
\text { membrane protein and membrane lysis, affect } \\
\text { respiration and cell division, drug efflux system }\end{array}$ & 84 \\
\hline
\end{tabular}

\subsection{Techniques to Determine Antibacterial Activity of Nanoparticles}

Various experimental methods and assays are available for measuring the antibacterial efficacy of nanoparticles. Each methods are unique and having their advantage and disadvantage. These methods/assays are (85):

- Optical density measurement

- $\quad$ Spread-plate(colony counts on agar)

- Cell counting devices

- Live/dead fluorescent stain MTS/MTT/XTT assays

- Crystal violet staining

\section{Conclusions}

In summary, it can be concluded that nanotechnology developed as a new approach in pharmaceutical sciences and research grasps great promise for overcoming complications related to delivery of antimicrobial and infection curing approaches. Various antimicrobial substances are unusable due to their instability, physicochemical limitations, enzyme degradation and cytotoxicity. Along with these problems, many microbes and their strains were getting resistant to the available antibiotics become as problem that surges the necessity to develop novel antibacterial substances. These issues were reasons for emergence of nanotechnology that provide many option for antimicrobials. The small size of the nanoparticles is very suitable for delivery of antibacterial substances.

\section{REFERENCES}

[1] Lam S, Wong EHH, Boyer C, Qiaoa GG. Antimicrobial Polymeric Nanoparticles. Progress in Polymer Science, 2017. https://doi.org/10.1016/j.progpolymsci.2017.07.007

[2] Morones JR, Elechiguerra JL, Camacho A, Ramirez JT. The bactericidal effect of silver nanoparticles. Nanotechnology 2005; 16: 2346-53.

[3] Kim JS, Kuk E, Yu KN, Kim JH, Park SJ, Lee HJ, et al. Antimicrobial effects of silver nanoparticles. Nanomed Nanotechnol Biol Med 2007; 3: 95-101.

[4] Zazo H, Millan, Colino CI, Lanao JM. Applications of Metallic Nanoparticles in Antimicrobial Therapy.
Antimicrobial Nanoarchitectonics,2017;411-17

[5] Gajjar P, Pettee B, Britt DW, Huang W, Johnson WP, Anderson J. Antimicrobial activities of commercial nanoparticles against an environmental soil microbe, Pseudomonas putida KT2440. Journal of Biological Engineering. 2009; 3: 9-22.

[6] Nakazato G, Kobayashi RKT, Seabra AB, Duran N. Use of nanoparticles as a potential antimicrobial for food packaging. Food Preservation, 2017; 413-447.

[7] Ferrari M. Cancer nanotechnology: opportunities and challenges. Nat Rev Cancer, 2005, 5, 3, 161-71.

[8] Gao W, Thamphiwatana S, Angsantikul P, Zhang L. Nanoparticle Approaches against Bacterial Infections. Wiley Interdiscip Rev Nanomed Nanobiotechnol. 2014; 6(6): 532547.

[9] Zhang L, Pornpattananangkul D, Hu CMJ, Huang CM. Development of nanoparticles for antimicrobial drug delivery. Curr Med Chem. 2010; 17:585-594.

[10] Das MR, Sarma RK, Saikia R, Kale VS, Shelke MV, Sengupta P. Synthesis of silver nanoparticles in an aqueous suspension of graphene oxide sheets and its antimicrobial activity. Colloids and Surfaces B: Biointerfaces 83 (2011) $16-22$.

[11] Parmar B, Mandal S, Petkar C, Patel LD, Sawant KK. Valsatran loaded solid lipid nanoparticle: development, characterization and in-vitro and ex-vivo evaluation. Int $\mathrm{j}$ Pharma Sci Nanotech, 2011, 4, 3, 1483-90.

[12] Albrecht MA, Evan CW, Raston CL. Green chemistry and the health implications of nanoparticles. Green Chem 2006; 8: 417-32.

[13] Wang P. Nanoscale biocatalyst systems. Curr Opinion Biotechnol 2006; 17: 574-9.

[14] Zhang L, Gu FX, Chan JM, Wang AZ, Langer RS, Farokhzad OC. Nanoparticles in medicine: therapeutic applications and developments. Clin Pharmacol Ther 2008; 83: 761-9.

[15] Hong B, Kai J, Ren Y, Han J, Zou Z, Ahn CH, et al. Highly sensitive rapid, reliable, and automatic cardiovascular disease diagnosis with nanoparticle fluorescence enhancer and MEMS. Adv Exp Med Biol 2008; 614: 265-73.

[16] Vigneshwaran N, Kathe AA, Varadarajan PV, Nachane RP, Balasubramanya RH. Functional finishing of cotton fabrics using silver nanoparticles. J Nanosci. Nanotechnol. 2007; 7: 1893-7.

[17] Conlon JM, Kolodziejek J, Nowotny N. Antimicrobial peptides from ranid frogs: taxonomic and phylogenetic 
markers and a potential source of new therapeutic agents. Biochim Biophys Acta 2004; 1696: 1-14.

[18] Kim D, Park S, Lee JH, Jeong YY, Jon S. Anti-biofouling polymer coated gold nanoparticle as a contrast agent for in vivo $\mathrm{x}$ ray commuted tomography imaging. J Am Chem Sci, $129,7661-7665$.

[19] Gopinath V, Ali DM, Priyadarshini S, Priyadarshini NM, Thajuddin N, Velusamy P. Biosynthesis of silver nanoparticles from Tribulus terrestri sand its antimicrobial activity: A novel biological approach. Colloids and Surfaces B: Biointerfaces 96 (2012) 69-74.

[20] Gong P, Li H, He X, Wang K, Hu J, Tan W, et al. Preparation and antibacterial activity of $\mathrm{Fe}_{3} \mathrm{O}_{4} @ \mathrm{Ag}$ nanoparticles. Nanotechnology 2007; 18: 604-11.

[21] Gu H, Ho PL, Tong E, Wang L, Xu B. Presenting vancomycin on nanoparticles to enhance antimicrobial activities. Nano Lett 2003; 3(9):1261-3.

[22] Ahmed S, Ahmad M, Swami BL, Ikram S. A review on plants extract mediated synthesis of silver nanoparticles for antimicrobial applications: A green expertise. Journal of Advanced Research (2015)

http://dx.doi.org/10.1016/j.jare.2015.02.007.

[23] Cho KH, Park JE, Osaka T, Park SG. The study of antimicrobial activity and preservative effects of nanosilver ingredient. Electro chimica Acta 51 (2005) 956-960.

[24] Shaker MA, Shaaban MI. Synthesis of silver nanoparticles with antimicrobial and anti-adherence activities against multidrug-resistant isolates from Acinetobacter baumannii. Journal of Taibah University Medical Sciences, 12, 4, 2017, 291-297.

[25] Ramyadevi J, Jeyasubramanian K, Marikani A, Rajakumar G, Rahuman AA. Synthesis and antimicrobial activity of copper nanoparticles. Materials Letters 71 (2012) 114-116

[26] Khan S, Ansari AA, Khan AA, Ahmad R, Al-Obaid O, Al-Kattan W. In vitro evaluation of anticancer and antibacterial activities of cobalt oxide nanoparticles. J BiolInorg Chem. 2015 Dec; 20(8):1319-26.

[27] Huang X, Chen X, Chen Q, Yu Q, Sun D, Liu J. Investigation of functional selenium nanoparticles as potent antimicrobial agents against superbugs. Acta Biomater. 2015 S1742-7061(15)30170-7. doi: 10.1016/j.actbio.2015.10.041.

[28] Roy A, Gauri SS, Bhattacharya M, Bhattacharya J. Antimicrobial activity of $\mathrm{caO}$ nanoparticles. J Biomed Nanotechnol. 2013;9(9):1570-8

[29] Wang Q, Perez JM, Webster TJ. Inhibited growth of Pseudomonas aeruginosa by dextran- and polyacrylicacid-coated ceria nanoparticles. Int J Nanomedicine. 2013; 8:3395-9.

[30] Nazari P, Dowlatabadi-Bazaz R, Mofid MR, Pourmand MR, et al. The antimicrobial effects and metabolomic footprinting of carboxyl-capped bismuth nanoparticles against Helicobacter pylori. Appl Biochem Biotechnol. 2014, 172(2):570-9.

[31] Siddique S, Shah ZH, Shahid S, Yasmin F. Preparation, characterization and antibacterial activity of $\mathrm{ZnO}$ nanoparticles on broad spectrum of microorganisms. Acta Chim Slov. 2013; 60(3):660-5.
[32] Brown AN, Smith K, Samuels TA, Lu J, Obare SO, Scott ME. Nanoparticles Functionalized with Ampicillin Destroy Multiple Antibiotic-Resistant Isolates of Pseudomonas aeruginosa and Enterobacter aerogenes and Methicillin-Resistant Staphylococcus aureus. Applied and Environmental Microbiology, 2012, p. 2768-2774.

[33] Rai A, Prabhune A, Perry CC. Antibiotic mediated synthesis of gold nanoparticles with potent antimicrobial activity and their application in antimicrobial coatings. J. Mater. Chem. 2010; 20:6789-6798.

[34] Sun RW, Chen R, Chung NP, Ho CM, Lin CL, Che CM. Silver nanoparticles fabricated in Hepes buffer exhibit cytoprotective activities toward HIV-1 infected cells. Chem Commun (Camb). 2005; 40:5059-61.

[35] Illangakoona UE, Mahalingama S, Wanga K, Cheong YK, Canales E, Ren GG et al., Gyrospun antimicrobial nanoparticle loaded fibrous polymeric filters. Materials Science and Engineering: C 74, 2017, 315-324.

[36] Chi Chen Y, Yu KP. Enhanced antimicrobial efficacy of thermal-reduced silver nanoparticles supported by titanium dioxide. Colloids and Surfaces B: Biointerfaces, 154, 2017, 195-202.

[37] Sundrarajan M, Bama K, Bhavani m, Jegatheeswaran S, Ambika S, Sangili A, Nithya P, Sumathi R. Obtaining titanium dioxide nanoparticles with spherical shape and antimicrobial properties using $\mathrm{M}$. citrifolia leaves extract by hydrothermal method. Journal of Photochemistry and Photobiology B: Biology, 171, 2017, 117-124.

[38] Beyth N, Yudovin-Farber I, Perez-Davidi M, Domb AJ, and Weiss EI, "Polyethylenimine nanoparticles incorporated into resin composite cause cell death and trigger biofilm stress in-vivo," Proceedings of the National Academy of Sciences of the United States of America, 107, 51, 22038-22043, 2010

[39] Sondi I and Salopek-Sondi B, "Silver nanoparticles as antimicrobial agent: a case study on E. coli as a model for Gramnegative bacteria," Journal of Colloid and Interface Science, 275, 1, 177-182, 2004.

[40] Choi O, Deng KK, Kim NJ, Ross Jr. L, Surampalli RY,Hu Z, "The inhibitory effects of silver nanoparticles, silver ions, and silver chloride colloids on microbial growth," Water Research, 42, 12, 3066-3074, 2008.

[41] Percival, S.L., Bowler, P.G., Russell, D., 2005. Bacterial resistance to silver in wound care. J. Hosp. Infect. 60, 1-7.

[42] Wright, J.B., Lam, K., Burrell, R.E., 1994. Wound management in an era of increasing bacterial antibiotic resistance: a role for topical silver treatment. Am. J. Inf. Control 26, 572-577.

[43] Pelgrift RY, Friedman AJ, "Nanotechnology as a therapeutic tool to combat microbial resistance," Advanced Drug Delivery Reviews, 65, 13-14, 1803-1815,2013.

[44] Blecher K, Nasir A, Friedman A, "The growing role of nanotechnology in combating infectious disease," Virulence, 2, 5,395-401, 2011.

[45] Kuo WS. Antimicrobial gold nanorods with dual-modality photodynamic inactivation and hyperthermia. Chem. Commun. 2009; 32: 4853-4855. 
[46] Weinberg ED. Iron loading and disease surveillance. Emerg Infect Dis. 1999; 5(3): 346-352.

[47] Sirelkhatim A, Mahmud S, Seeni A, Kaus NHM, Ann LC, Bakhori SKM, Hasan H, Mohd SK. Review on Zinc Oxide Nanoparticles: Antibacterial Activity and Toxicity Mechanism. Nano-Micro Lett. (2015) 7(3):219-242

[48] Reddy KM, Feris K, Bell J, Wingett DG, Hanley C, Punnoose A. Selective toxicity of zinc oxide nanoparticles to prokaryotic and eukaryotic systems. Appl Phys Lett. 2007; 90(213902):2139021-2139023.

[49] Padmavathy N, Vijayaraghavan R. Enhanced bioactivity of $\mathrm{ZnO}$ nanoparticles - an antimicrobial study. Sci Technol Adv Mat. 2008; 9(3):35004-35010.

[50] Han G, Martinez LR, Mihu MR, Friedman AJ, Fried-man JM, Nosanchuk JD. "Nitric oxide releasing nanoparticles are therapeutic for Staphylococcus aureus abscesses in a murine model of infection," PLoS ONE, 2009, 4, 11.

[51] Ansari MA, Khan HM, Khan AA, Cameotra SS, Saquib Q, Musarrat J, "Interaction of $\mathrm{Al}_{2} \mathrm{O}_{3}$ nanoparticleswith Escherichia coli and their cell envelope biomolecules," Journal of Applied Microbiology, 116,772-783,2014.

[52] Beyth N, Houri-Haddad Y, Domb A, Hazan R. Alternative Antimicrobial Approach: Nano-Antimicrobial Materials. Evidence-Based Complementary and Alternative Medicine, 2015, 246012, 16. http://dx.doi.org/10.1155/2015/246012

[53] Maneewattanapinyo P, Banlunara W, Thammacharoen C, Ekgasit S, Kaewamatawong T, "An evaluation of acute toxicity of colloidal silver nanoparticles," The Journal of Veterinary Medical Science, 73,11,1417-1423,2011.

[54] Campos AD, Diebold Y, Carvalho ELS, Sanchez A, Alonso MJ. Chitosan nanoparticles as new ocular drug delivery systems: in vitro stability, in-vivo fate, and cellular toxicity. Phafrma Res, 2004, 21, 5, 803-810

[55] Lichter JA, Rubner MF. "Polyelectrolyte multilayers with intrinsic antimicrobial functionality: the importance of mobile polycations," Langmuir, 25, 13, 7686-7694, 2009.

[56] Wang AZ, Farokhzad OC, Langer R, Nanoparticle Delivery of Cancer Drugs. Annu. Rev. Med. 2012. 63:185-98

[57] Beyth N, Houri-Haddad Y, Baraness-Hadar L, Yudovin-Farber I, Domb AJ, Weiss EI. Surface antimicrobial activity and biocompatibility of incorporated polyethylenimine nanoparticles. Biomaterials 29 (2008) 4157-4163.

[58] Jiaoa Y, Niua L, Maa S, Lic J, Tayd FR, Chena JH. Quaternary ammonium-based biomedical materials: State-of-the-art, toxicological aspects and antimicrobial resistance. Progress in Polymer Science, 71, 2017, 53-90.

[59] Fawaz F, Bonini F, Maugein j, Lagueny AM. Ciprofloxacin-loaded poly-iso-butylcyano acrylate nanoparticles: pharmacokinetics and in vitro antimicrobial activity. International Journal of Pharmaceutics 168 (1998) 255-259.

[60] Fontana G, Pitarresi G, Tomarchio V, Carlis B, Biagio PLS. Preparation, characterization and in vitro antimicrobial activity of ampicillin-loaded polyethylcyanoacrylate nanoparticles. Biomaterials 19 (1998) 1009-1017.
[61] Hindi KM, Ditto AJ, Panzner MJ, Medvetz DA, Hovis CE, Hilliard JK et al. The antimicrobial efficacy of sustained release silver-carbene complex-loaded L-tyrosine polyphosphate nanoparticles: Characterization, in vitro and in vivo studies. Biomaterials 30 (2009) 3771-3779.

[62] Toti US, Guru BR, mCpHARLIN cm, Wykes SM, Panyam J, Hudson JA. Targeted delivery of antibiotics to intracellular chlamydial infections using PLGA nanoparticles. Biomat, 2011, 32, 27, 6606-13

[63] Prombutara P, Kulwatthanasal Y, Supaka N, Sramala I, Chareonpornwattana S, Production of nisin-loaded solid lipid nanoparticles for sustained antimicrobial activity. Food Control 24 (2012) 184-190.

[64] Esmaeili F, Hosseini-Nasr M, Rad-Malekshahi M, Samadi N, Atyabi F, Dinarvand R. Preparation and antibacterial activity evaluation of rifampicin-loaded poly lactide-co-glycolide nanoparticles. Nanomedicine.2007; 3(2):161-167.

[65] Chaudhary J, Lakhawat S, Pathak AN.Elucidation on enhanced application of synthesized kojic acid immobilized magnetic and chitosan tri-polyphosphate nanoparticles as antibacterial agents. IET Nanobiotechnol. 2015 Dec; 9(6):375-80. doi: 10.1049/iet-nbt.2014.0077.

[66] Wang T, Chen X, Lu M, Li X, Zhou W. Preparation, characterisation and antibacterial activity of a florfenicol-loaded solid lipid nanoparticle suspension. IET Nanobiotechnol. 2015 Dec; 9(6): 355-61.

[67] Ortega A, Farah S, Tranque P, Ocaña AV, Nam-Cha SH, Beyth $\mathrm{N}$, et al. Antimicrobial evaluation of quaternary ammonium polyethyleneimine nanoparticles against clinical isolates of pathogenic bacteria. IET Nanobiotechnol. 2015, 9(6):342-8.

[68] Arasoglu T, Derman S, Mansuroglu B. Comparative evaluation of antibacterial activity of caffeic acid phenethyl ester and PLGA nanoparticle formulation by different methods. Nanotechnology. 2015 Dec 2; 27(2):025103.

[69] Vibe CB, Fenaroli F, Pires D, Wilson SR, Bogoeva V, Kalluru R, et al.. Thioridazine in PLGA nanoparticles reduces toxicity and improves rifampicin therapy against mycobacterial infection in zebrafish. Nanotoxicology. 2015 Nov 17:1-9.

[70] Barreras US, Méndez FT, Martínez RE, Valencia CS, Rodríguez PR, Rodríguez JP. Chitosan nanoparticles enhance the antibacterial activity of chlorhexidine in collagen membranes used for periapical guided tissue regeneration. MaterSciEng C Mater Biol Appl. 2016 Jan 1; 58:1182-7.

[71] Silva EL, Carneiro G, De Araújo LA, Trindade Mde J, Yoshida MI, et al. Solid Lipid Nanoparticles Loaded with Retinoic Acid and Lauric Acid as an Alternative for Topical Treatment of Acne Vulgaris. J Nanosci Nanotechnol. 2015; 15(1): 792-9.

[72] Stevanovic M, Uskokovic V, Filipovic M, Škapin SD, Uskokovic D. Composite PLGA/AgNpPGA/AscHnanospheres with combined osteoinductive, antioxidative, and antimicrobial activities. ACSAppl Mater Interfaces. 2013, 25; 5(18):9034-42.

[73] Mohammadi G, Nokhodchi A, Barzegar-Jalali M, et al. Physicochemical and anti-bacterial performance characterization of clarithromycin nanoparticles as colloidal 
drug delivery system. Colloid Surf B.2011;88 (1):39-44.

[74] Silva NC, Silva S, Sarmento B, Pintado M. Chitosan nanoparticles for daptomycin delivery in ocular treatment of bacterial endophthalmitis. Drug Deliv. 2015 Oct; 22(7):885-93.

[75] Vukomanovic M, Zavasnik-Bergant T, Bracko I, et al. Poly(D,L-lactide-co-glycolide)/hydroxyapatite coreshellnanospheres. Part 3: properties of hydroxyapatite nano-rods and investigation of a distribution of the drug within the composite. Colloid Surf B. 2011; 87(2):226-35.

[76] Turos E, Shim JY, Wang Y, Greenhalgh K, Reddy GS, Dickey S, Lim DV. Antibiotic-conjugated polyacrylate nanoparticles: new opportunities for development of anti-MRSA agents. Bioorg Med Chem Lett. 2007; 17: 53-56.

[77] Mohammadi G, Valizadeh H, Barzegar-Jalali M, et al. Development of azithromycin-PLGA nanoparticles: physicochemical characterization and antibacterial effect against Salmonella typhi. Colloid Surf B. 2010; 80(1):34-39.

[78] Ahmad Z, Pandey R, Sharma S, Khuller GK. Alginate nanoparticles as anti-tuberculosis drug carriers: formulation development, pharmacokinetics and therapeutic potential. Ind J Chest Dis Allied Sci 2005; 48:171-6.

[79] Mosqueira VC, Loiseau PM, Bories C, Legrand P, Devissaguet JP, Barratt G. Efficacy and pharmacokinetics of intravenous nanocapsule formulations of halofantrine in Plasmodium berghei-infected mice. Antimicrob Agents Chemother. 2004; 48(4):1222-1228.

[80] Shah LK, Amiji MM. Intracellular delivery of saquinavir in biodegradable polymeric nanoparticles for HIV/AIDS. Pharm Res. 2006; 23: 2638-2645.

[81] Gomes C, Moreira RG, Castell-Perez E. Poly (DL-lactide-co-glycolide) (PLGA) nanoparticles with entrapped trans-cinnamaldehyde and eugenol for antimicrobial delivery applications. J Food Sci. 2011; 76(2): N16-24.

[82] SinCheow W, Wook Chang M, Hadinoto K. Antibacterial Efficacy of Inhalable Levofloxacin-Loaded Polymeric Nanoparticles Against E. coli Biofilm Cells: The Effect of Antibiotic Release Profile. Pharm Res. 2010; 27:1597-1609.

[83] Hiraki J, "Basic and applied studies on $\varepsilon$-polylysine," Journal of Antibacterial and Antifungal Agents, vol.23, pp. 349-354, 1995.

[84] Ibrahim M, Tao Z, Hussain A et al., "Deciphering the role of Burk holder iacenocepacia membrane proteins in antimicrobial properties of chitosan," Archives of Microbiology, 196 ,1,9-16, 2014.

[85] Seil JT, Webster TJ. Antimicrobial applications of nanotechnology: methods and literature. International Journal of Nanomedicine 2012:7 2767-2781. 